\title{
TAXING THE MARKET CITIZEN: FISCAL POLICY AND INEQUALITY IN AN AGE OF PRIVATIZATION
}

\author{
LISA PHILIPPS*
}

\section{INTRODUCTION}

A new emphasis on privatization is rippling through many fields of state policy in various countries. The restructuring of tax policy to foster a more privatized social and economic order is often overlooked as an example of this pattern. Focusing on Canada, this article argues that recent efforts to revise important facets of the income tax system are best understood through the lens of privatization. That is, Canadian tax policy increasingly discourages people from relying upon government programs or services to meet their basic welfare needs, but encourages them to rely instead upon private resources obtained through the market, or, if necessary, from family or charity. I argue that by promoting personal responsibility in this manner, the tax code is contributing to an erosion of the ideal of social citizenship and replacing it with a new model of market citizenship. While the reforms may offer immediate fiscal benefits to some, the overall effect will heighten social inequalities, with specific effects on gender inequality.

Part II of the article expands on the concepts of privatization and market citizenship and considers their broad implications for social equality. Though privatization is often associated with deregulation and the withdrawal of the state, I suggest that it is better seen as a new regulatory project in which the state's role has merely shifted away from redistribution toward the legitimization and enforcement of market outcomes. Fiscal reform is a key element of this project, not only because of its role in allocating and distributing resources, but also because of its normative power. Changes to the tax law are actively reconstituting the ideal subject of politics around a norm of market citizenship. I

\footnotetext{
Copyright @ 2001 by Lisa Philipps

This article is also available at http://www.law.duke.edu/journals/63LCPPhilipps.

* Associate Professor, Osgoode Hall Law School of York University, Toronto, Canada. This paper was prepared for the international conference on Public Perspectives on Privatization, Geneva, Switzerland, July 16-18, 1999. The research was undertaken as part of a collaborative project on Feminism, Law and the Challenge of Privatization, funded by a grant from the Social Sciences and Humanities Research Council of Canada. I thank my colleagues in that project for many helpful conversations and suggestions, and particularly Brenda Cossman and Judy Fudge for detailed comments on earlier drafts. Neil Brooks and David Duff also provided helpful feedback during the writing of the paper. I am indebted to Olga San Miguel, Angela Long, Robert Kreklewich, and Freya Kodar for their superb research assistance.
} 
compare the concept of social citizenship associated with the welfare state to the new market citizenship of neoliberalism, in terms of their respective understandings of inequality and of gender relations. Just as feminists have exposed the gendered nature of social citizenship, they are beginning to discern how the gender order is being reconstituted within market citizenship. Drawing on this literature, I explain why the privatization of tax policies may exacerbate gendered inequalities.

The last two decades offer many examples of reforming Canadian tax law to encourage self-reliance. These reforms include greater tax incentives to save privately for retirement ${ }^{1}$ and post-secondary education, ${ }^{2}$ or to donate personal wealth to charities, which increasingly are assuming responsibility for social services. $^{3} \quad$ The tax system also has been used to convert formerly universal transfers such as the family allowance into means-tested programs that attempt to create incentives for wage earning. ${ }^{4}$

Part III of the article focuses on two current tax policy debates in Canada: the trend toward personal income tax cuts and the campaign for tax recognition of unpaid caregiving work. I argue that each of these developments demonstrates how tax policy is being deployed to promote the norms and practices of market citizenship. My case studies parallel the two private sectors that are meant to supply most of the resources for personal self-reliance: the market and the family. I analyze both areas of tax policy change in terms of their effect on gendered patterns of social inequality, including their likely impact on the distribution of income and on women in their capacities as market actors, unpaid caregivers, and welfare state clients. Together they illuminate the contradictory pressures placed on women to increase their market incomes while simultaneously absorbing more unpaid caregiving responsibilities in the family household. These initiatives demonstrate how tax policy is redistributing the costs of caring for people away from those who fare best in the market-including some women-to those who fare poorly.

1. See Barbara Austin, Policies, Preferences and Perversions in the Tax-Assisted Retirement Savings System, 41 MCGILL L.J. 571, 577-78 (1996); Claire F.L. Young, Public Taxes, Privatizing Effects, and Gender Inequality, in Challenging the Public/Private Divide: FEMINISM, LAW AND Public POLICY 307, 319-23 (Susan B. Boyd ed., 1997).

2. See generally Maureen Donnelly et al., Registered Education Savings Plans: A Tax Incentive Response to Higher Education Access, 47 CANADIAN TAX J. 81 (1999).

3. See generally Blake Bromley, New Rules for Charitable Giving, in 27 REPORT OF ProceEdings OF THE FORTY-NINTH TAX CONFERENCE 1 (1998); Neil Brooks, The Role and Financing of the Voluntary Sector in a Modern Welfare State, in CHARITIES: BETWEen STATE AND MARKET (Bruce Chapman et al. eds., forthcoming 2001) (on file with author); David Duff, Charitable Contributions and the Personal Income Tax: Evaluating the Canadian Credit, in CHARITIES: BETWEEN STATE AND MARKET, supra; Gordon Floyd, The Voluntary Sector in Canada's New Social Contract: More Responsibility But No Voice?, 13 PHILANTHROPIST 39 (1996); Michael H. Hall \& Paul B. Reed, Shifting the Burden: How Much can Government Dowload to the Non-Profit Sector?, 41 CANADIAN PuB. ADMIN. 1 (1998).

4. See generally Ken Battle, The National Child Benefit: Best Thing Since Medicare OR NEW POOR LAW? (1997); Frances Woolley \& Arndt Vermaeten, Ending Universality: The Case of Child Benefits, 22 CANADIAN PUB. POL'Y. 24 (1996). 


\section{From Social CiTIZENS TO MARKET CITIZENS: PRIVATIZATION AND TAX POLICY}

The central theme of this article is that recent tax reforms in Canada are promoting private responsibility for human welfare, signaling a shift away from the solidaristic ideals of social citizenship toward a more individualistic model of market citizenship. The term social citizenship can be traced to British sociologist T.H. Marshall, who divided modern citizenship conceptually into three elements: civil, political, and social, with the last developing only in the twentieth century. ${ }^{5}$ Marshall argued that the civil and political rights that emerged in the eighteenth and nineteenth centuries could not be exercised in any practical sense by the vast majority of people until social rights were also extended. ${ }^{6}$ By social rights he meant "the right to a modicum of economic welfare and security ... [and] the right to share to the full in the social heritage and to live the life of a civilized being according to the standards prevailing in the society." $7 \mathrm{He}$ associated these rights especially with public education and social services. ${ }^{8}$

Marshall identified the introduction of progressive taxes as one of the major factors enabling the rise of social rights because it helped to reduce inequality; this reduction encouraged a political struggle to reduce it even further. ${ }^{9}$ What emerged from these struggles was a new conception of social rights as universal and integral to the status of citizenship, as opposed to the stigmatizing poorrelief measures of the nineteenth century. Though economic inequalities would by no means disappear, the expansion of in-kind benefits and subsidies could confine their significance largely to non-essential forms of consumption. The objective, as Marshall put it, was to ensure a level of universal programs such that "[t]he provided service, not the purchased service, becomes the norm of social welfare."

The egalitarian ideals of social citizenship, in turn, provided the normative basis for an increasingly robust state funded by progressive taxation. Marshall drew an important connection between citizens' enjoyment of social rights and their acceptance of a duty to pay such taxes. ${ }^{11}$ With the rise of the Keynesian welfare state, tax policy gained a prominent status as one of the most powerful levers available to government in its new role as active regulator of the market economy. Redistributive taxation and spending policies came to be seen as both equitable and efficient. Ensuring a basic standard of living to all citizens

5. See T.H. Marshall, Citizenship and Social Class, in Sociology AT THE CROSSROADS AND OTHER EsSAYS 67 (T.H. Marshall ed., 1963).

6. See id. at 74 .

7. $I d$.

8. See id.

9. See id. at 100 .

10. Id. at 108. For a discussion of the development of universal social security in Canada, see JANE Ursel, Private Lives, Public Policy: 100 Years of State InTERVENTION IN THE FAmily 204 (1992).

11. See Marshall, supra note 5, at 122. 
not only was considered fair, but it supported mass demand for consumer goods and therefore served the purpose of moderating market recessions. ${ }^{12}$ The degree of actual progress toward equality under different welfare states should not be exaggerated. Certainly, Canadian social services were among the least ample of all welfare states, never attaining a level of universality or comprehensiveness comparable to the Scandinavian or West European models. ${ }^{13}$ It is nevertheless true that social citizenship operated as an ideal against which programs could be evaluated and justified. The provision of a basic social safety net to protect against arbitrary market forces became closely identified with what it meant to be a citizen of Canada. ${ }^{14}$

The notion of universal social citizenship opened up new space for marginalized groups, including women, to make claims for full inclusion in political and economic affairs. ${ }^{15}$ Organized women's groups gained recognition as legitimate participants in policy formation and lobbied successfully for state funding and initiatives to promote women's equality. In Canada, this recognition included the appointment of a Royal Commission on the Status of Women to recommend steps "to ensure for women equal opportunities with men in all aspects of Canadian society ...." ${ }^{\prime 16}$ Notably, this initiative was almost simultaneous with the Report of the Royal Commission on Taxation (the "Carter Commission"), which still represents the high water mark of egalitarian, redistributive tax policymaking in Canadian history. ${ }^{17}$ Thus, the flourishing of social citizenship was associated both with a progressive tax system that could improve equity across economic strata and with fuller equality rights for women. The institutions of the welfare state became a crucial source of relatively good jobs for women, as well as a source of public assistance for women and their children in need.

Despite these advances, however, feminist scholars have criticized welfare states for creating a gendered and unequal form of social citizenship. ${ }^{18}$ For women, the scope for achieving substantive equality was ultimately constrained by the implicit gender order underpinning welfare states, which is based on the

12. See G.B. Doern et Al., Public Budgeting in CAnada: Politics, Economics and MANAGEMENT 2-4 (1991).

13. See generally G. ESPING-ANDERSON, THREE WORLDS OF WELFARE CAPITALISM (1990).

14. See Janine Brodie, Restructuring and the New Citizenship, in RETHINKING RESTRUCTURING: GENDER AND CHANGE IN CANADA 129 (Isabella Bakker ed., 1996).

15. See Janine Brodie, Shifting Public Spaces: A Reconsideration of Women in the Era of Global Restructuring, in THE STRATEGIC SILENCE: WOMEN AND ECONOMIC POLICY 53-54 (Isabella Bakker ed., 1994).

16. RePOrt of THE ROYAl COMMISSION ON THE STATUS OF WOMEN vii (1970).

17. See generally 1 REPORT OF THE ROYAL COMMISSION ON TAXATION (1966).

18. See, e.g., Diane Sainsbury, Gender Equality And Welfare States (1996); Patricia M. Evans, Divided Citizenship? Gender, Income Security and the Welfare State, in WOMEN AND THE Canadian Welfare State: Challenges and Change 91 (Patricia M. Evans \& Gerda R. Wekerle eds., 1997); Julia S. O'Connor, Gender, Class and Citizenship in the Comparative Analysis of Welfare State Regimes: Theoretical and Methodological Issues, 44 BRITISH J. SOC. 502 (1993); Ann Shola Orloff, Gender and the Social Rights of Citizenship: The Comparative Analysis of Gender Relations and Welfare States, 58 AM. SOC. REV. 303 (1993). 
ideal of a family wage sufficient to allow a male breadwinner to support a wife whose primary role would be the provision of caregiving labor at home. Taxation and other public policies were designed with this normative family in mind, despite the fact that in real life it described only a narrow group of relatively privileged, heterosexual, mostly white families. ${ }^{19}$ As a consequence, the distribution of entitlements tended to follow a highly gendered pattern. The most generous and least stigmatized programs typically have been wage replacement measures, such as unemployment insurance and retirement pensions, available mostly to men because they are conditioned upon substantial labor market participation. Women, more often have obtained social benefits via their status as dependents or mothers, or through minimal welfare programs for those entitled to nothing else. Therefore, despite advancing women's equality interests in a variety of ways, welfare states also reinforced a gendered division of labour that limited women's access to paid work and their ability to survive economically without a male partner.

When Marshall wrote about the rise of social rights, he acknowledged the inherent limitations and tensions in a system that attempts to combine the principle of social justice with the logic of the market. ${ }^{20}$ To the extent that the liberal welfare state did subordinate the market to the demands of social welfare, however, the rise of neoliberalism can be seen as an inversion of this process. The central theme of the neoliberal challenge to the welfare state is that market forces are to be preferred over state regulation as a means of allocating resources and distributing income and wealth. The primacy of markets is asserted not only as efficient and morally just, but as an absolute necessity for nations to thrive in an increasingly global economy. Neoliberalism calls upon governments to relinquish regulatory control over production, trade, and investment, both domestically and across international borders, and to transfer as many state assets and functions as possible to private actors. ${ }^{21}$ It also advocates restructuring government so that remaining state operations will emulate private enterprise more closely. ${ }^{22}$

Just as the state's role is reimagined, so are the terms of citizenship, to emphasize individual self-reliance, competition, and consumer choice. The ideal citizen of neoliberal discourse is responsible to secure his or her own welfare

19. See Shelley A.M. Gavigan, Paradise Lost, Paradox Revisited: The Implications of Familial Ideology for Feminist, Lesbian, and Gay Engagement to Law, 31 OsGOODE HALL L.J. 589 (1993); Kathleen Lahey, The Political Economies of "Sex" and Canadian Income Tax Policy (1998) (unpublished manuscript, on file with author).

20. See Marshall, supra note 5, at 101, 123-27.

21. See Stephen McBride \& John Shields, Dismantling a Nation: The Transition to Corporate Rule in CANAda 17-31 (2d ed., 1997); GARY TeEPle, Globalization AND the DECLINE OF SOCIAL REFORM 75-127 (1995); Isabella Bakker, Deconstructing Macro-economics Through a Feminist Lens, in WOMEN AND CANADIAN PUBliC POLICY 31, 33-36 (Janine Brodie ed., 1996); Marjorie Griffin Cohen, From the Welfare State to Vampire Capitalism, in WOMEN AND THE CANAdian Welfare STATE, supra note 18, at 28; Nancy Fraser, Clintonism, Welfare, and the Antisocial Wage: The Emergence of a Neoliberal Political Imaginary, 6 RETHINKING MARXISM 9 (1993).

22. See generally Harry Arthurs, "Mechanical Arts and Merchandise": Canadian Public Administration in the New Economy, 42 MCGILL L.J. 29 (1997). 
through market activity, family resources, and, if necessary, charity, resorting to government assistance only in the most desperate circumstances. ${ }^{23}$ Public services once associated with universal social rights are increasingly restricted, means-tested, and made more closely conditional upon efforts to engage in paid labour. The egalitarian vision of social citizenship, still incompletely realized, is being displaced by a norm of market citizenship in which inequalities are attributed to individual merit or failures, and social rights are displaced by economic rights to private property and free markets.

The turn to neoliberalism has dramatic implications for tax policy. Like other regulatory levers of the welfare state, the use of taxation to stabilize the economy and redistribute market income has begun to attract suspicion. Such economic activism is now derided as inefficient as well as unfair to successful market actors. The decline of social citizenship has eroded the normative basis for progressive taxation, just as the globalization of markets has eroded its economic basis. Gary Teeple offers the following explanation:

\begin{abstract}
As long as capital remained distinctly national, it had an interest in allowing a part of its revenue to be collected as taxes for the purposes of maintaining the national state, or more precisely, the general conditions of production. When capital began to lose its character as a national existence, it began to find fewer advantages in contributing tax revenues to the "nation"... . Their enormous size, economic power, and increased mobility have allowed companies to reduce taxation by playing nations off against nations. $^{24}$
\end{abstract}

Efforts to coordinate tax systems internationally to prevent avoidance have been minimal and largely unsuccessful. ${ }^{25}$ The consequent downward shifting of the tax burden to lower and middle income workers, combined with the declining social services provided by the state, contributes to a generalized hostility to taxation and a sense that public services must be too costly or governments too wasteful. ${ }^{26}$ As discussed infra, ${ }^{27}$ this dynamic is evident in the level of political pressure currently being applied in Canada and elsewhere for personal income tax cuts.

However, it would be a mistake to equate privatization simply with deregulation or the withdrawal of the state. This study of tax reform confirms that the state is by no means withering away, but that its power is being redirected from social provisioning to the task of coercing and cajoling citizens into a new market order. ${ }^{28}$ As Rod MacDonald has written, "[t]he free market is a specific

23. See Brodie, supra note 14; Janine Brodie, Meso-Discourses, State Forms and the Gendering of Liberal-Democratic Citizenship, 1 CITIZENSHIP STUdIES 223 (1997); Carole Pateman, Contributing to Democracy, 4 REV. CONST. STUD. 191, 193 (1998).

24. TEEPLE, supra note 21, at 95.

25. See Sol Picciotto, Offshore: The State as Legal Fiction, in OFFSHORE FINANCE CENTRES AND

TAX Havens: The Rise of Global CaPital 43 (Mark P. Hampton \& Jason P. Abbott eds., 1999).

26. See TEEPLE, supra note 21 , at 96 ; Cohen, supra note 21 , at 36.

27. See discussion infra accompanying notes 35-73.

28. See JANine Brodie, Politics on the MARgins: Restructuring AND the CANAdian Women's MOVEMENT 51 (1995); see also Claude Denis, "Government Can Do Whatever It Wants": Moral Regulation in Ralph Klein's Alberta, 32 CANADIAN REV. SOC. \& ANTH. 365 (1995). 
regulatory choice which is the product of very sophisticated state initiatives." ${ }^{29}$ Tax law must be viewed in this light, as a key instrument for creating and regulating a social order premised on private self-reliance. The examples discussed in the next part of this article show how the tax system continues to be busily employed by government policymakers to influence behaviour, both by diverting resources to favoured activities and by cultivating norms about the appropriate role of the state and the meaning of good citizenship.

A critical dimension of this neoliberal regulatory project is to invent a gender order that will cohere with the privatization of responsibility for social welfare. As Nancy Fraser has pointed out, the old gender order, based on the assumption of a sole breadwinner family, has dissolved, but the neoliberal state remains deeply confused about what model of gender relations should now inform public policy. ${ }^{30}$ One of the striking features of neoliberalism is its official gender neutrality, in that it imposes the rigours of the market on women as well as men without regard to women's caregiving roles or unequal access to paid work. Perhaps the most powerful illustration is the extension of workfare requirements to mothers on social assistance. ${ }^{31}$ However, there is a burgeoning feminist literature demonstrating that the ostensible gender blindness of neoliberal market discipline merely obscures the highly gendered effects of privatizing responsibility for social welfare. ${ }^{32}$ Calling upon citizens to support themselves via the market or the family demands that women intensify both their paid labour-to support household incomes in a less secure labor market — and their unpaid care work - to offset the retraction of health care and other social services. Moreover, women are placed in this tightening double bind at precisely the same moment that governments are defunding a range of equality-enhancing initiatives, such as child care services, employment equity programs, and women's advocacy groups. The apparent efficiencies of neoliberal policies are thus achieved in part by burying more of the costs of maintaining people in a longer (paid and unpaid) workday for women. The discourse of market citizenship presumes that everyone has access to private resources, ignoring the conditions of class, race, gender, and other dimensions of inequality "that determine when, how and which people can exercise

29. Roderick A. MacDonald, Understanding Regulation by Regulations, in REGULATIONS, CROWN CORPORATIONS AND ADMINISTRATIVE TRIBUNAls 81, 116 (I. Bernier \& A. Lajoie eds., 1985).

30. See Nancy Fraser, After the Family Wage: A Postindustrial Thought Experiment, in JUSTICE INTERRUPTUS: CRITICAL REFLECTIONS ON THE "POST-SOCIALIST" CONDITION 41 (1997).

31. See Evans, supra note 18.

32. See, e.g., Isabella Bakker, Identity, Interests and Ideology: The Gendered Terrain of Global Restructuring, in GLOBALIZATION, DEMOCRATIZATION AND MULTILATERALISM 127 (Stephen Gill ed., 1996); BRODIE, supra note 28; SASKIA SASSEN, GLOBALIZATION AND ITS DISCONTENTS 81-109, 111131 (1998); Brodie, supra notes 14, 15, 23; Martha MacDonald, Gender and Social Security Policy: Pitfalls and Possibilities, 4 Feminist ECON. 1 (1998); Ingrid Palmer, Public Finance From A Gender Perspective, 23 WORLD DEV. 1981 (1995); Katherine Scott, The Dilemma of Liberal Citizenship: Women and Social Assistance Reform in the 1990s, 50 STUD. POL. ECON. 7 (1996). 
'individual' responsibility ...." ${ }_{33}$ In these ways, neoliberal restructuring both intensifies and denies the problem of gendered social inequalities. To the extent that such inequalities are acknowledged, they are attributed to the outcomes of private ordering and thereby constructed as natural and nonpolitical..$^{34}$

The tax reforms considered infra illuminate the contradictory and vulnerable position of women in the market model of citizenship. Designing tax policies to promote private self-reliance places specific and often competing pressures on women in their various roles as market actors and unpaid caregivers. Although these policies offer immediate fiscal benefits to some individual women, they ultimately call upon women to absorb more of the costs of social welfare. And, as these costs are shifted onto women, they are also redistributed from those women who fare well in the market to those who do not. The two areas of tax reform examined in the balance of this article will have more benign effects on women with access to higher incomes, either through the market or the family, than on low wage earning women and women who rely more heavily on social programs.

III

\section{TwO STORIES OF PRIVATIZING TAX REFORM}

\section{A. Income Tax Cuts: Liberating the Market Citizen}

Governments in Canada and elsewhere are presently under intense pressure to cut taxes and especially to reduce the level of personal income tax-the most progressive element of the Canadian tax system and by far the biggest revenue raiser. $^{35}$ Other levies, such as sales taxes and property taxes, are not geared to ability to pay and tend to be regressive because they take a larger proportion of lower incomes than of higher incomes. The personal income tax is really the only component of the Canadian tax system that gives it significant redistributive potential. Thus, the attack on progressive income taxes can be understood as a direct challenge to the redistributive role of the liberal state.

The case for tax cuts is based loosely on a combination of supply-side economics and libertarian politics. It is presented as a means to spur economic growth by increasing private consumption and investment and by preventing an alleged "brain drain" of talented (meaning high income) Canadians to the

33. Marlee Kline, Blue Meanies in Alberta: Tory Tactics and the Privatization of Child Welfare, in Challenging the Public/Private Divide: Feminism, LAW AND Public Policy 330, 338 (Susan Boyd ed., 1997).

34. See BRODIE, supra note 28 , at 28-31.

35. See R. Howard et al., Federal Tax Changes and Marginal Tax Rates, 1986 and 1993, 43 CANAdiAn TAX J. 906 (1995); G.C. Ruggeri et al., The Redistributional Impact of Taxation in Canada, 42 CANAdian TAX J. 417 (1994); Frank W. Vermaeten et al., Tax Incidence in Canada, 42 CANADIAN TAX J. 348 (1994). In 1996, personal income taxes accounted for about $46 \%$ of federal government revenue and about $31 \%$ of revenue of all levels of government. 
United States. ${ }^{36}$ But there is also a distinct moral and political tone to the argument. Tax cut advocates talk about ending government oppression of taxpayers and allowing individuals to retain more of their hard-earned income.

The campaign to reduce progressive income taxes is privatizing in that it seeks to bolster the role of market forces and individual choice in shaping the social and economic order. This is not because governments are starving themselves of revenue, at least not yet. However, the concern is that income tax cuts will alter the distribution of the overall tax burden to be less progressive. In addition, their normative impact cannot be discounted. The discourse of tax cutting constructs market income as individually earned and deserved, making the state's claim on that income presumptively illegitimate or at least suspect. People are portrayed as better off meeting their own needs privately, by keeping and spending more of their market income, than by having public services and programs made available to them. The effect is to depoliticize inequality of access to income, goods, and services in the private sphere of the market. This section will particularly investigate the possible gendered effects of tax cuts given women's lesser access to market incomes and greater provision of unpaid caregiving labour.

Personal income taxes can be reduced in a variety of different ways, with different impacts. At the heart of the Canadian income tax system is the progressive rate structure established by the federal Income Tax Act ("ITA")." The marginal rates applicable to individuals from 1993 to 1999 were as follows: ${ }^{38}$

\begin{tabular}{ll}
\hline On income up to $\$ 29,590$ & $17 \%$ \\
On income from $\$ 29,590$ to 59,180 & $26 \%$ \\
On income exceeding $\$ 59,180$ & $29 \%$ \\
\hline
\end{tabular}

It should be noted that the $17 \%$ rate takes effect only after a taxpayer has earned more than the threshold amount eligible for the basic personal credit granted by the ITA, effectively creating a zero rate bracket at the bottom of the

36. See, e.g., Rick EGELTON \& WOJCIECH SZADURSKI, TRENDS IN CANADA-U.S. MigRATION: WHERE'S THE FlOOD? (Bank of Montreal Economic Analysis, Mar. 24, 1999); SCOTT MURRAY, BRAIN DRAIN OR BRAIN GAIN? WHAT DO THE DATA SAY (1998); see also Robert D. Brown, Tax Reform and Tax Reduction: Let's Do the Job Right, 47 CANADIAN TAX J. 182 (1999). Most empirical studies do not support the existence of a serious brain drain or the notion that income tax rates play a dominant or even significant role in the decision of some individuals to take up opportunities abroad. Neil Brooks, Flattening the Claims of Flat Taxers, 21 DALHOUSIE L.J. 287, 357-66 (1998); John Zhao et al., Brain Drain and Brain Gain: The Migration of Knowledge Workers from and to Canada, 6 EDUC. Q. REV. 8 (2000).

37. See Income Tax Act, R.S.C., ch.1 (1985) (Can.) [hereinafter ITA].

38. See id. 5th Supp., § 117 (2). 
rate structure..$^{39}$ In addition, the marginal rate is affected by surtaxes, which are levied as a percentage of federal tax payable. ${ }^{40}$

The two most obvious methods of delivering a general income tax cut would be to reduce one or more of the percentage rates or to increase the size of the brackets so that the higher rates apply to a smaller proportion of a taxpayer's income. In either case, the distributive impact would depend on which brackets or rates were altered, and by how much. In this regard, Revenue Canada data indicate that more than half of those filing tax returns in 1996 had incomes under $\$ 30,000 .^{41}$ Further, Table 1 indicates that women taxpayers are overrepresented among those earning up to $\$ 20,000$, all of whom fall into the lowest federal rate bracket, while men are over-represented among those with incomes over $\$ 20,000$. In all income groups, whether under or over $\$ 20,000$, women's average income is lower than men's (Table 2). Rate reductions targeted to those in either the middle (twenty-six percent) or the upper (twenty-nine percent) brackets will therefore benefit only a minority of taxpayers, most of whom are men. This is true both in terms of the number of male versus female taxpayers in these brackets, and in terms of the quantum of the tax cut enjoyed by men versus women in the two upper brackets. When viewed against this demographic background, the tax reduction plans announced by the federal government betray a considerable class and gender bias.

The 2000 federal budget proposed to reduce the twenty-six percent middle rate to twenty-four percent as of July 1, 2000, and to twenty-three percent within five years. ${ }^{42}$ Though ostensibly a tax cut for ordinary, middle-class Canadians, this change provides virtually no benefit to those earning less than $\$ 30,000$, who comprise the majority of taxpayers and are primarily women. Likewise, the government's decision to index the income brackets fully to inflation and to increase the thresholds to at least $\$ 35,000$ and $\$ 70,000$, respectively, within five years will provide no immediate tax savings to those earning less than the current threshold of $\$ 29,590$. Such individuals may eventually benefit from the expansion of the lowest bracket, but only if they receive cost of living increases that raise their salaries above $\$ 29,590$.

The federal government has also moved to eliminate surtaxes. The general surtax, equal to three percent of income tax payable, was abolished as of Janu-

39. See id. $\S 118(1)$ (c). The basic personal amount for 2000 is $\$ 7,131$. See discussion infra note 49 and accompanying text.

40. See id. $\S 180.1$. See discussion infra note 43 and accompanying text.

41. See Hugh MacKenzie, Who's Really Winning Here? The Real Story of the Martin Tax Cut Budget, 2 BEHIND THE NUMBERS, Feb. 29, 2000, at 1. MacKenzie's conclusions are supported by the author's own analysis of the data, which indicates that $68 \%$ of all returns were filed by people with incomes of zero- $\$ 30,000$ in 1996 . Even when only taxable returns were counted, $54 \%$ were filed by those with incomes in this range. See CANAdA CUSTOMS And Revenue Agency, All Returns by Age, Sex, Total Income Class and Major Source of Income, in TAX STATISTICS ON INDIVIDUALS-1998 EDITION (July 19, 2000) (visited Nov. 6, 2000) <http://www.ccra-adrc.gc.ca/tax/individuals/stats/gb96/ pts96/t06-ftot.htm>. The author thanks Freya Kodar for her stoical assistance with all the statistical data presented in this section of the article. 2000].

42. See Canada DeP'T. Fin., Budget 2000: The Budget Plan 87 (2000) [hereinafter Budget 
ary $1,2000 .^{43}$ The distributive effect of this tax cut is plainly regressive: It provides savings that rise with a taxpayer's income. Even more regressive is the elimination of the five percent higher income surtax, proposed in the 2000 budget, which will reduce taxes exclusively for those earning over about $\$ 65,000$, the overwhelming majority of whom are men. ${ }^{44}$

Perhaps the most regressive federal tax cuts to date, however, are the concessions announced in the 2000 budget for those who receive capital gains, essentially the profits earned when capital property-such as real estate or shares-appreciates in value over its original cost to the owner. Most capital gains are received by a tiny group of very high-income taxpayers. Data from 1996 show that $57.3 \%$ of capital gains on corporate shares, and $63.2 \%$ of capital gains on all types of property, were reported by the $1.6 \%$ of taxpayers who had incomes of $\$ 100,000$ or more..$^{45}$ As Table 1 indicates, less than eighteen percent of this elite group are women. It is not surprising, then, that in 1996 men reported more than twice the amount of aggregate capital gains as women. ${ }^{46}$ Certainly some lower and middle income taxpayers receive capital gains and will benefit to some extent from the capital gains tax cuts in the 2000 budget. The statistics indicate, however, that they will benefit far less than high income taxpayers. Only about five percent of those earning $\$ 40,000$ or less reported any capital gains at all in 1996, compared to almost forty percent of those earning $\$ 100,000$ or more. $^{47}$ Among those who earned no more than $\$ 20,000$ in 1996 , a group that was mostly female and comprised $52.4 \%$ of all tax filers that year, fewer than four percent reported any capital gains at all, and in total, they received only $5.2 \%$ of the total capital gains reported. ${ }^{48}$

The class and gender regressivity of the federal tax cut plan is moderated slightly by the decision to increase the basic personal exemption from $\$ 7,131$ to at least $\$ 8,000$ within five years. ${ }^{49}$ This change will provide a federal tax cut of $\$ 148$ to every individual who earns $\$ 8,000$ or more. The incidence of this measure is progressive in that the $\$ 148$ tax saving represents a larger proportion of income for those in the lower brackets. However, it must be noted that in terms of dollar amounts the elimination of surtaxes is potentially far more valuable on an individual level. This is because the maximum benefit of increasing the basic personal exemption is $\$ 148$ for all taxpayers, while the dollar value of removing the three percent and five percent surtaxes rises indefinitely with a taxpayer's income. Thus, two people with $\$ 20,000$ and $\$ 100,000$ of income, respectively, will each save $\$ 148$ in federal tax due to the higher personal amount, whereas

43. See ITA, R.S.C., ch. 1, 5th Supp., § 180.1(a) (1985) (Can.).

44. See id. The 5\% surtax applies to federal tax payable in excess of $\$ 12,500$. According to the 2000 federal budget, it is to be eliminated gradually over a five-year period.

45. See CANADA Customs AND REVENUE AGENCY, supra note 41, tbl. 9.

46. See id. tbl. 4

47. See id. tbl. 9.

48. See id.

49. See BudGet 2000, ch. 4, tbl. 4.1 (2000). 
the abolition of surtaxes will be worth about $\$ 1,082$ to the $\$ 100,000$ earnermost likely a man-and only $\$ 61$ to the $\$ 20,000$ earner-most likely a woman. ${ }^{50}$

TABLE 1

All RETURnS By InCOME Class \& SEX, 1996 TAXATION YeAR

\begin{tabular}{lcccc}
\multicolumn{2}{c}{ Men } & \multicolumn{2}{c}{ Women } \\
\hline Income Class & Total No. & $\begin{array}{c}\% \text { of } \\
\text { Income Class }\end{array}$ & Total No. & $\begin{array}{c}\% \text { of } \\
\text { Income Class }\end{array}$ \\
\hline$<\$ 10,000$ & $2,143,880$ & 37.8 & $3,529,270$ & 62.2 \\
$\$ 10,000-20,000$ & $2,139,630$ & 40.9 & $3,089,970$ & 59.1 \\
$\$ 20,000-30,000$ & $1,669,860$ & 50.4 & $1,641,500$ & 49.6 \\
$\$ 30,000-40,000$ & $1,414,970$ & 57.3 & $1,054,600$ & 42.7 \\
$\$ 40,000-50,000$ & $1,044,780$ & 65.7 & 545,280 & 34.3 \\
$\$ 50,000-100,000$ & $1,637,180$ & 74.6 & 558,430 & 25.4 \\
$>\$ 100,000$ & 276,830 & 82.2 & 59,790 & 17.8 \\
Total & $10,327,130$ & 49.6 & $10,478,840$ & 50.4 \\
\hline
\end{tabular}

Source: CAnada Customs and Revenue Agency, All Returns by Age, Sex, Total Income Class and Major Source of Income, in TAX STATISTICS ON INDIVIDUALS-1998 EDITION (JULY 19, 2000).

TABLE 2

Total AND AVERAGE TAXABLE INCOME PER SEX AND InCOME Class, 1996 TAXATION YEAR

\begin{tabular}{lcccc} 
& \multicolumn{2}{c}{ Men } & \multicolumn{2}{c}{ Women } \\
\hline Income Class & $\begin{array}{c}\text { Taxable Income } \\
\text { Assessed } \\
\text { (thousands of } \$)\end{array}$ & $\begin{array}{c}\text { Average } \\
\text { Taxable Income } \\
(\text { mean) }\end{array}$ & $\begin{array}{c}\text { Taxable Income } \\
\text { Assessed } \\
\text { (thousands of } \$)\end{array}$ & $\begin{array}{c}\text { Average } \\
\text { Taxable Income } \\
(\text { mean })\end{array}$ \\
\hline$<\$ 10,000$ & $7,664,205$ & $\$ 3,575$ & $12,089,987$ & $\$ 3,426$ \\
$\$ 10,000-20,000$ & $26,836,084$ & $\$ 12,542$ & $35,346,203$ & $\$ 11,439$ \\
$\$ 20,000-30,000$ & $38,001,745$ & $\$ 22,757$ & $37,097,928$ & $\$ 22,600$ \\
$\$ 30,000-40,000$ & $44,659,739$ & $\$ 31,562$ & $32,616,844$ & $\$ 30,928$ \\
$\$ 40,000-50,000$ & $41,890,727$ & $\$ 40,095$ & $21,363,479$ & $\$ 39,179$ \\
$\$ 50,000-100,000$ & $93,279,035$ & $\$ 59,975$ & $30,376,781$ & $\$ 54,396$ \\
$>\$ 100,000$ & $50,009,076$ & $\$ 180,649$ & $9,266,736$ & $\$ 154,988$ \\
Total & $302,340,611$ & $\$ 29,276$ & $178,157,958$ & $\$ 17,002$ \\
\hline
\end{tabular}

Source: Canada Customs And Revenue Agency, All Returns by Age, Sex, Total Income Class and Major Source of Income, in TAX STATISTICS ON INDIVIDUALS-1998 EDITION (JULY 19, 2000).

50. The tax savings from eliminating the surtaxes have been estimated using the proposed new brackets and rate structure under the 2000 federal budget, and assume that each taxpayer is entitled to claim only the basic personal credit. See CANADA CUSTOMS AND REVENUE AGENCY, supra note 41, at 88 . 
The federal rates do not tell the full story, as the provinces also levy personal income taxes computed as a percentage of an individual's federal tax payable. ${ }^{51}$ Provincial governments have led the way in cutting taxes in Canada. This article focuses on Ontario and Alberta, the two most aggressive tax-cutting jurisdictions in the country. Ontario is an excellent case study, not only because the Conservative government has defined itself around the issue of reducing taxes, but also because it started cutting earlier than other provinces so that it is possible to observe some actual impacts. Between 1996 and 2000, Ontario's personal income tax rate was reduced by about one-third, from $58 \%$ to $38.5 \% .{ }^{52}$ The rate reduction is the same for all taxpayers, but because provincial tax was computed as a percentage of federal tax, which is in turn based on progressive marginal rates, the benefits of the Ontario rate reduction rise with income. ${ }^{53}$

Notably, the tax cuts in Ontario have not translated into smaller government. On the contrary, the government's own statistics show that total revenue as a share of Gross Domestic Product ("GDP") is set to increase slightly from fifteen percent in 1995, the year the Conservatives were first elected, to $15.3 \%$ in 1999-2000..$^{54}$ What has changed, however, is the composition of the revenue stream. Whereas personal income taxes comprised $31.6 \%$ of provincial revenues in the 1995-96 fiscal year, that figure was projected to fall to twenty-seven percent in 1999-2000. ${ }^{55}$ The province now draws a larger share of its revenue from sources that have a less progressive or even regressive incidence, such as retail sales taxes (up from $19.1 \%$ to $20.8 \%$ of total revenue), corporations tax (10.5 to $13.4 \%$ ), and casino revenues $(.85 \%$ to $1.71 \%) .{ }^{56}$ It has also relied more heavily on sales and rentals of government assets, a category that represented one percent of total revenue in 1995-96 and was projected to rise to $3.83 \%$ in $1999-2000 .^{57}$ Thus, Ontario has undercut the redistributive capacity of its tax system both by giving the biggest income tax cuts to higher income earners and by changing the fiscal mix so that government relies more heavily on nonprogressive sources of revenue.

The Ontario experience with tax cutting shows clearly that privatization is less a matter of deregulation than a new regulatory project to produce a more market-oriented society. While the provincial government is not occupying any less space in the private economy, it now does less to redistribute and more to

51. All provinces except Quebec have entered tax collection agreements under which the federal government administers the provincial tax on condition that it is expressed simply as a flat percentage of federal tax payable. That is, the provinces simply adopt the tax base as defined by the federal ITA. The tax collection agreements are soon to be amended to allow the provinces to impose tax as a percentage of federally defined taxable income, giving them greater control over the rate structure and credits under the provincial income tax system. See DEPARTMENT OF FINANCE - CANADA, FEDERAL ADMinisTration of PROVINCIAL TAXES: NEW DiRECTIONS Annex 2 (2000).

52. See Income Tax Act, R.S.O., ch. I-2, § 4 (1990) (Can.) [hereinafter Ontario ITA].

53. See Ontario ITA $\S 3$. The regressivity of the tax cut has been partially offset by an increase in the high-income surtaxes.

54. See Ontario Ministry of FinAnCE, 1999 Ontario Budget 57 (1999).

55. See id. at 53,60 .

56. See id.

57. See id. 
reinforce the market distribution of income. This dynamic certainly is not limited to Ontario. Many other jurisdictions around the world have experienced a similar trend toward lower marginal income tax rates and heavier reliance on non-progressive sources of revenue, with the result that "effective tax rates have risen at the low end of the earnings scale." ${ }^{58}$ Again, to the extent that women are concentrated in lower income brackets, this shift will tend to exacerbate both class and gender economic inequalities.

The province of Alberta is undertaking even more dramatic reforms to its income tax rate structure. It will divorce itself from federal progressive rates and instead impose a flat rate of $10.5 \%$ on the taxable income of provincial residents, ${ }^{59}$ a change that will deliver the greatest tax relief to those with high incomes. Alberta's proposal represents a historic moment in Canadian fiscal history. Income taxes have been synonymous with graduated rates since the early twentieth century, when they were first enacted federally. ${ }^{60}$ The explicit rejection of this system in Alberta in favour of a proportional rate suggests an important shift toward greater acceptance of market outcomes as just and efficient, as well as a lesser commitment to the state as a moderating influence on social inequalities. This faith in the market as an ordering mechanism was evident in Alberta Treasurer Stockwell Day's remarks upon introducing the flat tax, that "[t]he single rate makes the system fair for everyone and eliminates the disincentive to earn more and work harder." ${ }^{\prime 11}$ Echoing these themes, Day's successor, Treasurer Steve West, claimed that “Alberta's amended personal tax system will have a great impact on the economy, creating 30,000 jobs within the next five years and increasing GDP growth by nearly $\$ 2$ billion, or $1.5 \%$. ${ }^{, 62}$

Importantly, Alberta's scheme does not completely abandon the idea of ability to pay as a criterion for determining relative tax burdens. At the same time that it moves to a flat rate, the province has also announced that it will increase its basic personal exemption amount to $\$ 12,900$, more than sixty percent higher than the $\$ 8,000$ being proposed federally. ${ }^{63}$ In effect, this means that the Alberta system will still have two rates: zero on income up to $\$ 12,900$, and $10.5 \%$ on any excess. Increasing the basic personal exemption benefits all those with taxable income, including the most affluent, but it enhances progressivity because it delivers greater proportional tax relief to lower-income individuals. It is also probably the least male-biased method of delivering general income tax relief because women are overrepresented among low-income earners.

\footnotetext{
58. ORgANisATION FOR ECON. COOP. AND DEV., OECD ECONOMIC OUTLOOK 181 (1998).

59. See Alberta Personal Income Tax Act, R.S.A., ch. A-35.03, § 4 (2000) (Can.).

60. See Richard Krever, The Origin of Federal Income Taxation in Canada, 3 CANADIAN TAX. 170

61. Alberta Prepares the Way for a Bold New Tax System with Bill 18, Alberta Gov't. Press Release (Mar. 16, 2000) (visited Dec. 6, 2000) <http://www.gov.ab.ca/acn/200003/8916.html>.

62. Amended Bill 18 Increases the Alberta Advantage over Other Provinces, Alberta Gov't. Press Release (May 23, 2000) (visited Dec. 6, 2000) < http://www.gov.ab.ca/acn/200005/9173.html>.

63. It will also raise the dependent spouse credit to $\$ 12,900$. See Alberta Personal Income Tax Act, R.S.A., ch. A-35.03.
} (1981). 
In evaluating the merits of this strategy, however, it is important not to lose sight of the larger impact of tax cuts. Any form of income tax cut, no matter how progressively it is designed, may erode government revenues. To the extent that governments replace those revenues through regressive levies such as user fees or sales taxes, they may simply recover the money from the same people in a different form. Alternatively, the government may respond to a revenue loss by cutting transfer payments or public services that are of greatest value to the poorest people. As many researchers have pointed out, the withdrawal of public health, education, and social services has an especially harsh effect on women, as public sector employees, as consumers of welfare state services, and as caregivers whose unpaid labour is increasingly called upon to ensure that the needs of the elderly, children, the ill, and the disabled continue to be met despite declining public programs. ${ }^{64}$ To put the point concretely, a single mother earning $\$ 30,000$ may benefit from an income tax cut, but she may find that her take home pay is simultaneously eroded by new or higher fees in the public health care or school systems, or for her children's daycare or recreational activities. She may also have to miss work to take care of a sick relative who is sent home early from hospital, or may worry that her children do not have access to the same quality of education as others, or that she may lose her job in the public sector. Tax cuts, even those targeted to lower income earners, must be examined as part of a total package of neoliberal fiscal policies that has troubling implications for social inequality.

Adding to the downward pressure on income taxes are the tax referendum laws introduced recently by some provinces, including Ontario. ${ }^{65}$ Unlike the United States or Switzerland, for example, Canada does not have a strong tradition of direct voting on political questions. However, one of the most striking developments in Canadian politics since the 1980s is the sudden enthrallment with referenda and other forms of "direct" or "participatory" democracy. Taxation has become one of the main lightning rods for this populist sentiment. Three provinces so far have tabled legislation that would prohibit their governments from raising tax rates unless they first receive approval in a referendum. ${ }^{66}$ The creation of extra-legislative controls on taxation is unprecedented in Canada. Indeed, fiscal policymaking has been more tightly controlled by the executive branch of government than almost any other area of policy. The appearance of tax referendum laws suggests a dramatic surge of public hostility toward taxation, and it seems likely that they will operate at least as a political disincentive to any government thinking about reversing the income tax cuts of recent years.

64. See supra note 32.

65. See Lisa C. Philipps, The Rise of Balanced Budget Laws in Canada: Legislating Fiscal (Ir)responsibility, 34 OSGOODE HALL L.J. 681 (1996).

66. See Balanced Budget, Debt Repayment and Taxpayer Protection Act, R.S.M., ch. 7, § 10 (1995) (Can.); see also Taxpayer Protection and Balanced Budget Act, R.S.O., ch. 7, sched. B (1999) (Can.). The Alberta government tabled a comparable tax referendum law, Bill 26, the No Tax Increase Act, which received first reading on June 2, 1997. It died on the order paper and was never reintroduced. 
The notion that tax referenda will enhance the level of democracy in Canada is highly simplistic. It does not address the many criticisms of referenda identified by political theorists, including their propensity to completely override minority interests and their failure to secure meaningful consent from groups that are disadvantaged in deliberative politics. ${ }^{67}$ The U.S. experience with fiscal populism certainly shows that direct democracy mechanisms are just as susceptible as elections to manipulation and domination by powerful and well-organized lobby groups. ${ }^{68}$ It is especially troubling that these laws single out tax increases as the one fiscal policy decision that citizens must be able to veto directly. Ironically, they seek to enhance democracy by curtailing the power of the state, the only institution that can counter the undemocratic exercise of private power in markets. Likewise, they conceive of the taxpayer, the owner of market resources, as the only citizen who deserves a greater voice in government. The laws allow for no public veto of government-imposed user fees or spending cuts, for example, measures that typically impose the greatest burden on those who have low incomes or rely relatively more on public services. The privileging of taxation as the defining or most onerous element of the state-society relation reveals the deeply gendered nature of market citizenship. It obscures entirely the role of women's unpaid work in meeting social welfare needs and propping up an ailing public sector. This unpaid work has itself been likened to a tax that women must pay before they are free to engage in incomeearning activities in the market. ${ }^{69}$ The new referendum laws obscure this implicit tax from view because they associate citizenship rights only with the control of market income. ${ }^{70}$

The entire agenda of tax cutting coheres well with the new norms of market citizenship, emphasizing the power to express preferences and exercise private property rights in the marketplace over the power to hold governments politically accountable for the quality or accessibility of public services. This is strongly evident in the remarks of the Ontario legislative committee that recommended a tax referendum law for the province: "Taxes bind citizens economically, and ... the level of taxation is fundamental to both the health of the economy .... and to the economic well being of the individual. If citizens are going to be bound in such a fundamental way, they must have a voice." ${ }^{, 1}$

67. See Referendums: A Comparative Study of Practice And Theory 34-37 (David Butler \& Austin Ranney eds., 1978); Derrick A. Bell, Jr., The Referendum: Democracy's Barrier to Racial Equality, 54 WASH. L. REV. 1 (1979); Diane Dwyre et al., Disorganized Politics and the Have-Nots: Politics and Taxes in New York and California, 27 J. NE. PoL. SCI. Ass'N. 25; Priscilla F. Gunn, Initiatives and Referendums: Direct Democracy and Minority Interests, 22 URB. L. ANN. 135 (1981).

68. See Daniel A. Smith, TAx Crusaders and the Politics of Direct Democracy (1998), Elizabeth Garrett, Who Directs Direct Democracy? 4 U. CHI. L. REV. 17, 18 (1997).

69. See Isabella Bakker \& Diane Elson, Toward Engendering Budgets, in ALTERNATIVE FEDERAL Budget PAPERS 1998, at 297, 299 (Canadian Centre for Policy Alternatives. ed., 1998); Palmer, supra note 32, at 1983.

70. See Ruth Lister, Women, Economic Dependency and Citizenship, 19 J. Soc. POL'Y 445, 455-58 (1990); Pateman, supra note 23, at 199.

71. Legislative Assembly of Ontario, Standing Committee on the Legislative ASSEMBLY, FINAL REPORT ON REFERENDA 9-10 (June 1997). 
While market citizenship is presented as gender-neutral and universally accessible to all those prepared to work in the private economy, it is important to ask who will actually enjoy the benefits of any increased consumption and investment power generated by income tax cuts. I have argued in this section that groups who remain marginalized in markets, including women, are likely to be further disempowered by the overall effects of tax cuts, even if they do receive a small reduction in their tax bills.

\section{B. Tax Relief for Unpaid Caregiving Work: Family Values and Feminist Strategies}

Neoliberal policies that conceive of individuals as self-reliant and atomistic are backed by an assumption, whether stated or not, that individuals live in supportive families. Behind each ideal market citizen is assumed to stand a family that will facilitate market access (by providing childcare and other services) and provide back-up resources when market income is not available. Increasingly, state policies are demanding, explicitly or implicitly, that people turn first to family to meet their social welfare needs before they seek assistance from government. In practice, this means relying on women family members, both as primary caregivers who cushion the impact of declining public services and as wage earners who shore up household finances. It also means relying on poorly paid domestic labour, often provided by immigrant women and women of colour, without the labour law protections afforded to other workers. Women and men who achieve success in the market do so in part by exploiting the labour of women of colour. ${ }^{72}$

The tax system is now being drawn into the emerging debate in Canada over how to address women's tightening double bind of paid and unpaid work, generating a rash of recent proposals, discussed infra, to give tax relief for caregiving work provided within families. I argue that these proposals are not well designed to improve women's economic equality. While a higher visibility for women's unpaid labour is welcome, the tax reforms being suggested do little more than legitimate the reprivatization of social welfare costs onto families.

It is important to appreciate that recent efforts to use the tax system to value women's unpaid work have been shaped not only by neoliberalism but also by two other, very distinct political forces: the morally conservative "family values" movement $^{73}$ and feminist organizations. ${ }^{74}$ An international feminist campaign

72. See Brodie, supra note 14, at 217 (citing Abigail B. Bakan \& Daiva K. Stasiulis, Structural Adjustment, Citizenship, and Foreign Domestic Labour: The Canadian Case, 58 SCI. \& SoC'Y. 7 (1994)); see also Evelyn Nakano-Glenn, From Servitude to Service Work: Historical Continuities in the Racial Division of Paid Reproductive Labour, 18 SIGNS 1 (1992).

73. This includes political parties such as the Reform Party of Canada (now renamed the Canadian Conservative Reform Alliance Party), as well as advocacy groups, such as Focus on the Family (Canada), R.E.A.L. Women of Canada, the Canada Family Action Coalition, and the Home School Legal Defense Association.

74. These include international umbrella groups, such as the International Women Count Network, as well as Canadian organizations such as Mothers are Women. See Meg Luxton \& Leah F. Vo- 
on unpaid work has gathered momentum in recent decades to respond to neoliberal budget cuts "which simply transfer costs from the public sector service economy where they do show up in the national accounts to the care economy where they do not ...." 75 In response to this campaign, governments of many countries, including Canada, have made promises not only to measure the value of unpaid work, but to use this data in public policy formation to improve women's economic equality. ${ }^{76}$ At the same time, a morally conservative strain within the new right has begun using the language of valuing women's unpaid work to protest the decline of the traditional male breadwinner model of the family and to advocate policies that will encourage more women to forego paid work in favour of full-time caregiving. The following remarks from one Member of Parliament identified with the family values movement illustrates how feminist discourses about caregiving are being appropriated, while at the same time, feminists are held responsible for devaluing women's unpaid work:

UNPAID WORK IS STILL WORK:

The gravest social injustice of all time has to be the abandonment of the stay-at-home mother. Managing the family home and caring for our children was and continues to be the most important job in the world. It is an honourable profession which has been discouraged by those who are advocating for women who choose to work outside of the home.

Recent tax proposals relating to unpaid work thus reflect an uneasy mixture of neoliberal, feminist, and moral conservative ideas in current policy debate.

First on the table was the announcement in 1998 of a new caregiver tax credit aimed at those who have an elderly or infirm relative living in their home. The credit reduces tax liability by a maximum of $\$ 400$ per annum for taxpayers residing with an adult relative who fits into one of two categories: (1) a parent or grandparent who is age 65 or older or (2) a relative who is dependent on the taxpayer because of a physical or mental infirmity. ${ }^{78}$ The government has presented the caregiver credit as a means of delivering on its commitment to value women's unpaid work. ${ }^{79}$ For a number of reasons, however, it does this extremely poorly. The trivial amount of the credit obviously makes it no more

sko, Where Women's Efforts Count: The 1996 Census Campaign and "Family Politics" in Canada, 56 STUD. POL. ECON. 49 (1998).

75. Diane Elson, Gender Budget Initiative: Background PAPERS 9 (1999).

76. See generally Luxton and Vosko, supra note 74; see generally also Isabella Bakker, Unpaid Work and Macroeconomics: New Discussions, New Tools for Action, STATUS OF WOMEN CANADA (August 1998); MacDonald, supra note 32, at 7. For a history of Statistics Canada's efforts to measure the value of unpaid work since the early 1970s, see Chris Jackson, The Valuation of Unpaid Work at Statistics Canada, 2 FEMINIST ECON. 145 (1996).

77. Paul Szabo, Strong Families ... Make a Strong Country 49 (1997).

78. See ITA, R.S.C., ch. 1, 5th Supp., § 118(1) (1985), amended by R.S.C. ch. 22 § 31(2) (1999) (Can.). For the purposes of the credit, an adult relative includes any person who is at least 18 years old and who is a child, grandchild, parent, grandparent, brother, sister, aunt, uncle, nephew or niece of the taxpayer. The legislation attempts to limit the credit to situations where the relative is financially dependent. The maximum credit is reduced if the relative's income exceeds $\$ 11,500$ and is lost entirely if he or she has $\$ 13,853$ or more income in the year.

79. See Secretary of State for the Status of Women Hedy Fry, Comments in the House of Commons, Mar. 4, 1999, Hansard Serv., no. 189 at 1230. 
than a token gesture toward caregivers, not even approaching the actual value of the work provided. As such, it implicitly requires the input of large amounts of unpaid labour. Moreover, in many situations it will provide no benefit to the caregiver directly but will instead be claimed by a man on the basis of his female partner's caregiving work. This is because the credit is non-refundable, so that it can benefit only an individual with sufficient tax liability to absorb it, and can be claimed by any member of the household, whether they actually did any caregiving work for the aged or infirm relative. Households in which all members have very low incomes, or receive only non-taxable forms of income such as social assistance, will gain nothing from the caregiver credit. That the government made any budgetary decision with women's unpaid work in mind indicates that feminists have made some progress in raising political awareness of the gender impact of privatizing responsibility for human welfare. However, as currently designed, the new credit provides little direct recognition for caregivers' work, nor does it significantly increase their access to independent resources. Instead, it relies on the traditional reasoning that primary caregivers will be looked after privately by male breadwinners and legitimizes policymakers' assumptions that public healthcare, elder-care, and other services can be replaced by women's unpaid work.

A variety of other tax proposals relating to families and caregiving are circulating, though only the caregiver credit has been legislated. Most of these have been championed by conservative family values groups who assert that "tax discrimination" against single-earner couples is penalizing parents who choose to have one spouse provide full-time care for children at home. ${ }^{80} \mathrm{Be}-$ cause Canada's income tax is based on an individual unit of taxation, it is true that a family breadwinner with an income of $\$ 60,000$, for example, will generally be taxed more heavily under progressive rates than if both spouses were employed with salaries of $\$ 30,000$ each. The child-care expense deduction may widen this differential, as one member of the two-earner couple can deduct up to $\$ 7,000$ per annum per child for daycare or other child care costs that enable the taxpayer to engage in certain income-earning or educational activities. ${ }^{81}$

The superficial logic of the tax discrimination charge is misleading in several ways. It is mathematically misleading because it compares only the income tax burden and not the full living costs of the one-earner and two-earner couple. The child care expense deduction, for example, typically compensates for well under half of the real cost of full-time child care. Once the full expenses of having two parents in the paid work force are factored in (including child care, transportation, clothing, payroll taxes), in most cases they will have less take-

80. See, e.g., the March 4, 1999 Parliamentary motion of the Reform Party of Canada that "the federal tax system should be reformed to end discrimination against single income families with children." Hansard Serv., no. 189 at 1010.

81. See ITA, R.S.C., ch. 1, 5th Supp., § 63 (1985) (Can.). The maximum claim is $\$ 7,000$ for each child under seven, and $\$ 4,000$ for children aged seven to 15 . Under the definition of "child care expense" in $\S 63(3)$ of the Act, the caregiver cannot be the child's mother or father, or a minor child or other minor relative of the taxpayer claiming the deduction. 
home pay than the one-earner couple, despite bearing a lesser income tax burden. ${ }^{82}$ The complaint of tax discrimination also ignores the compelling policy reasons for choosing an individual unit of taxation, including the basic principle that a person should be taxed only on income that he or she controls, and the need to avoid the high marginal tax rate that is imposed on secondary (usually women's) earnings if the income of spouses is aggregated on a single return. ${ }^{83}$

Despite the weakness of their basic premise and their obvious negativism toward mothers who work for pay, moral conservatives have succeeded in attracting a great deal of attention to several proposals designed to reduce the tax burden on traditional-looking one-earner families with children. One of their most popular ideas is to extend the deduction for child-care expenses to families with a stay-at-home parent, to "end the discrimination against parents who provide child care at home." ${ }^{\text {4 }}$ Another popular idea is to allow breadwinners to split their income with a dependent spouse for tax purposes. This could be done by introducing joint filing, or less radically by allowing a breadwinner to transfer a limited amount of income to a caregiver spouse, which would then be deducted from his return and added to hers. ${ }^{85}$ Other countries, including the United States and Australia, have seen similar campaigns for tax reform to promote a morally conservative vision of family. ${ }^{86}$ These proposals are blatantly problematic for women's equality as they seek quite openly to revive stereotypical gender role assignments and to reserve control over market income to the breadwinner spouse. All are designed carefully to give tax benefits to breadwinners, leaving them to share the additional resources as they please (or not) with their dependent spouse. Moreover, they would deliver the greatest benefits to high-income breadwinners and are usually framed to exclude nonnormative families, such as single mothers or gay and lesbian couples. Therefore, though sometimes presented as a means of valuing women's unpaid work,

82. See Response of THE GOVERnMENT OF CANADA TO THE COMMUNICATION OF BEVERLEY SMITH TO THE UNITED NATIONS COMMISSION ON THE STATUS OF WOMEN 21-22 (1999).

83. See Neil Brooks, The Irrelevance of Conjugal Relationships in Assessing Tax Liability, in TAX UnITS AND THE TAX RATE SCAlE 35 (John G. Head \& Richard Krever eds., 1996); Maureen Maloney, What is the Appropriate Tax Unit for the 1990's and Beyond, in ISSUES IN THE TAXATION OF INDIVIDUALS 116 (Allan M. Maslove ed., 1994); EDWARD J. MCCAFFERY, TAXING WOMEN (1997); Julie A. Nelson, Feminist Theory and The Income Tax, in FEMINISM, OBJECTIVITY AND ECONOMICS 97 (1996).

84. ReForm Party of CANAda, Blue Sheet: Principles \& Policies of the Reform PARTY OF CANADA-1996-97 (1997). This idea has been endorsed by family values groups such as the Canada Family Tax Coalition, and also by New Democratic Party Members of Parliament. See also KENNETH J. BOESSENKOOL \& JAMES B. DAVIES, C.D. HOWE INST. COMMENTARY No. 117, GIVING MOM AND DAD A BREAK: RETURNING FAIRNESS TO FAMILIES IN CANADA'S TAX AND TRANSFER SYSTEM 23-26 (1998).

85. See, e.g., Bill C-256, An Act to amend the Income Tax Act, private member's bill introduced by M.P. Paul Szabo (1994) (recommending that taxpayers be allowed to split up to $\$ 20,000$ of their income with a stay at home parent); Progressive Conservative PARTY of CANADA, Designing A BLUEPRINT FOR CANADIANS (1997); R.E.A.L. WOMEN OF CANADA, POSITION PAPER ON PENSION AND TAX REFORM (visited Dec. 20, 2000) http://www.realwomenca.com/html/pension_and_tax _reform.html (recommending a joint spousal tax unit).

86. See MCCAFFERY, supra note 83; Miranda Stewart, Domesticating Tax Reform: The Family in Australian Tax and Transfer Law, 21 SYDNEY L. REV. 453 (1999). 
moral conservatives apparently view this work as valuable only when it is provided within a two-parent heterosexual family to the exclusion of any market work by the primary caregiver. The fact that wage-earning women generally perform a second shift of caregiving work when they get home is completely disregarded. In addition to advancing conservative family values, these proposals also tend to support neoliberal efforts to privatize social welfare costs to families by emphasizing women's caregiving responsibilities. Feminists need to intervene in these tax policy debates to ensure that the principle of valuing women's caregiving work is not appropriated for agendas that are less concerned with gender equality than with reducing social welfare expenditures or resisting women's entry into markets.

\section{CONCLUSION}

This article has provided some examples of how tax law is being used in Canada to produce a shift away from social citizenship toward a market model of citizenship that stresses private responsibility for human welfare. Implementing this shift requires the state to strengthen economic incentives and cultural pressures for self-reliance, and tax policy is proving to be an attractive medium for advancing these imperatives. The intensity of tax-reform debates and the wide range of views as to how exactly taxes should be cut and for which individuals and families illustrates that privatization is not just a matter of deregulation but of active reregulation. Distributive inequalities produced by markets and families are labeled private-placing them beyond political contestation-but are nonetheless the product of state initiatives in the tax field and elsewhere.

The gendered dimensions of privatization are evident in the pressures on women to be self-reliant market actors, while also compromising their own market access in order to take care of others. To echo Joan C. Williams, "our system provides care for children [and others] by economically marginalizing their caregivers." ${ }^{87}$ The tax reform proposals examined in this article, both for personal income tax cuts and for tax relief related to unpaid caregiving work, demonstrate how the transfer of welfare costs to markets and families may simply deepen these gendered economic inequalities, while at the same time immunizing them from political challenges. Most of the reforms that have been implemented or proposed so far would confer the greatest benefits on one group, comprised mostly but not exclusively of white men who are high-income earners, especially those with a stay-at-home spouse. Increasingly, Canadian tax policy looks to reward these successful market citizens, whose economic power and autonomy is conditioned in large part upon the provision of unpaid or low paid caregiving services by women family members or domestic workers.

87. Joan C. Williams, Restructuring Work and Family Entitlements Around Family Values, 19 HARV. J.L. \& PUB. POL'Y 753, 754 (1996). 
This critique raises the question of whether and how such tax proposals could be revised to address these inequities. Tax cuts could be targeted more carefully to give the most benefit to those with lower incomes. Tax relief for unpaid work would have to be radically increased and revised to ensure that it was refundable, providing benefits directly to the caregiver and recognizing the care work done by women who also work for pay. While such design improvements would not be insignificant, they would not alter the underlying project of privatization that these tax proposals represent. The very essence of this project is to foster and naturalize the inequalities of wealth and power that are endemic to private relations that once were made problematic by the ideal of social citizenship. 